\title{
Uluslararası İletişim Düzeninde Karşılıklı Bağımlılık ve Reform
}

\section{Elif Toprak}

ÖZ

Uluslararası iletişim düzenindeki asimetrik karşılıkı bağımlılık, reform tartışmalarına yol açmaktadır. Alanyazında bu sorun sıklıkla eleştirel kuram bağlamında özellikle ekonomi politik açıdan ele alınmıştır. Uluslararası Iliş̧kiler'in temel paradigmaları realizm ve liberalizme göre yapılandırılmış olan ve güç ilişkilerine dayalı bu düzende, reforma yönelik çabalar beklentileri karşılamaktan uzaktır. Bu çalışmanın amacı, soruna farklı bir açıdan yaklaşarak, iki baskın teorinin uluslararası iletişim düzeninde reforma yönelik katkı potansiyellerinin incelenmesidir. Neorealist ve neoliberal analizlerde sosyolojik ve normatif unsurların giderek daha fazla dikkate alınmasının gerekçesi yine küreselleşmeyle artan karşııılı bağımlııktır. Dolayısıyla bu teorik çalışmada, karşııkıı bağımlılık ve reform kavramlarının, uluslararası iletişimin farkı analiz düzeylerini içeren (1) enformasyon toplumu, (2) kültürlerarası iletişim ve kamu diplomasisi ve (3) küresel yönetişim unsurları bağlamında betimsel ve karşılaşıımalı bir analizi yapılmaktadır. Teorik çerçeve olarak realizm ve liberalizmin seçilmesinin nedeni, realist ve liberal temellere dayalı iletişim düzeninde reformun yine bu teorilerin kavramları üzerinden tartışılmasının faydalı olacağı tezidir. Reform ve çözüm çabalarında politika üretilmesi ve harekete geçilmesi beklenen alanlar; küresel bir enformasyon toplumu, ortak değer ve çıkarlar için uluslararası kamuoyunun oluşturulmasını sağlayacak kamu diplomasisi uygulamaları ve uluslararası kuruluşlar aracıllğıyla daha etkin ve adil bir küresel yönetişimdir.

Anahtar Sözcükler: Uluslararası Illetişim Düzeni, Kültürlerarası Iletişim, Karşılıkı Bağımlılık, Küresel Yönetişim, Enformasyon Toplumu

\author{
ELIF TOPRAK \\ Prof. Dr. \\ Anadolu Üniversitesi \\ etoprak1@anadolu.edu.tr \\ ORCID ID: 0000-0002-4098-3676
}

SELÇUK ILETIŞIM DERGISI 2021; 14(2): 754-783

doi: 10.18094/ JOSC.868518

Geliş Tarihi: 26.01.2021 Kabul Tarihi: 08.03.2021 Yayın Tarihi: 25.04.2021 
Mutual Interdependence and

Reform in International

Communication Order
JOURNAL OF SELÇUK

COMMUNICATION 2021;

14(2): $754-783$

doi: $10.18094 /$ JOSC.868518

\title{
Elif Toprak
}

\begin{abstract}
In the international communication order, the asymmetry in mutual interdependence leads to discussions on reform. In the literature, this dilemma is mostly studied through political economic lenses of the critical theory. The major paradigms, realism and liberalism in International Relations have shaped the structure of this order based on power relations and the efforts for a reform have been far away from meeting the expectations. The purpose of this paper is to approach the problem differently and investigate the potential of these theories for a reform. In the neorealist and neoliberal analyses, the sociological and normative concerns are increasingly taken into consideration also owing to increasing mutual interdependence with globalization. Therefore, in this theoretical paper, a descriptive and comparative analysis of the concepts mutual interdependence and reform is made according to (1) information society, (2) intercultural communication and public diplomacy and (3) global governance that involve different levels of analysis in international communication. The theoretical framework is constructed on realism and liberalism because of the thesis that a discussion on reform according to their perspective may prove more fruitful since the communication order is already based on realist and liberal concepts and arguments. In the quest for reform, the issue areas that require policies and action are a global information society, public diplomacy for an international public opinion and an effective and just global governance through initiatives of the international organizations.
\end{abstract}

Keywords: International Communication Order, Intercultural Communication, Mutual Interdependence, Global Governance, Information Society

\author{
ELIF TOPRAK \\ Prof. Dr. \\ Anadolu University \\ etoprak1@anadolu.edu.tr \\ ORCID ID: 0000-0002-4098-3676 \\ JOURNAL OF SELÇUK COMMUNICATION 2021; 14(2): 754-783 \\ doi: 10.18094/ JOSC.868518
}




\section{Giriş}

Uluslararası iletişim düzeninde asimetrik ve hatta hiyerarşik bir karşılıklı bağımlılı̆ın bulunması karşısında uluslararası toplum, bu realist ve liberal düzende reform ve gerçek anlamda küresel bir enformasyon toplumuna ulaşımasının yollarını aramaktadır. Bu reform arayışları, eşitsizliğin hakim olduğu platformlarda neoliberal çizgide devam etmekte ancak kültürel farklılıklar ve etik kaygılar yeterince gündeme alınamamaktadır. Küreselleşme özünde değerlerin evrenselleşmesinden bir hayli uzaktır. Her alanda etkilerini hissettiren karşılıklı bağımlıık, güç dengelerine göre şekillendiği ve asimetrik olduğu sürece, küreselleşme toplumlar için farklı anlamlar taşıyacaktır. Türdeş olmayan küreselleşme; teknoloji, finans altyapısı ve bilgiye erişimde demokratik veya eşitlikçi değildir. İletişim teknolojileriyle bilgiye erişimin kolaylaşması, uluslararasılaşma için gerekli beceri ve yetkinliklere (örneğin hareketlilik imkânına) sahip olanlar için söz konusudur. Bu dezavantajlı durum, özellikle gelişmekte olan ülkelerin reform taleplerine ve uluslararası ilişkilerde istikrarsızlığa yol açabilmekte, bu istikrarsızlı̆ın küresel etkisi ise gelişmiş ülkelerde daha korumacı politikalar olabilmektedir.

Uluslararası Illişkiler disiplininde temel paradigmalar olan realizm ve liberalizme göre, uluslararası siyasette merkezi bir otoritenin/hükümetin bulunmamasından kaynaklanan anarşik yapı, uluslararası sistemin rekabetçi ortamına ve aktörlerin küreselleşmeye farklı anlamlar yüklemesine neden olmaktadır. Örneğin gelişmiş ülkeler tarafından küreselleşme Batının demokratik değerlerinin yayılması ve evrenselleşme olarak anılırken, gelişmekte olan ve az gelişmiş ülkeler için sömürgeciliğin yeni bir evresidir. Aynı durum karşııklı bağımlıı̆ın tanımlanmasında ve uluslararası iletişimde reform ihtiyaçlarının belirlenmesinde de geçerlidir. Alanyazında bu durum sıklıkla eleştirel kuram bağlamında özellikle ekonomi politik açıdan ele alınmaktadır. Bu analiz ve eleştirilere göre, ekonomik olarak güçlü olan devletler ve küresel ekonomide söz sahibi olan şirketler, iletişim ortam ve araçlarını da şekillendirir ve bağımlılık ilişsisini devamlı kılar. Uluslararası ilişkilerde temel paradigmalar olan realizm, liberalizm, ekonomik yapısalcılık ve yorumsamacı yaklaşımlar olan konstrüktivizm, eleştirel teori ve normatif teori uluslararası ilişkileri kendi kavramlarıyla açıklamaya ve yorumlamaya çalışır (Viotti \& Kauppi, 2012, s. 1216). Realizm ve liberalizme göre göre yapılandırılmış ve güç ilişkilerine dayalı iletişim düzeninde, reform ve küresel enformasyon toplumunun inşasına yönelik çabaların yetersizliğini sorgulayan çalışmalarda teorik çerçeve olarak sıklıkla yorumsamacı yaklaşımlar kullanılmaktadır. Bu çalışmanın amacı, soruna 
farklı bir açıdan yaklaşarak, iki baskın teorinin, realizm ve liberalizmin uluslararası iletişim düzeninde reforma yönelik katkı potansiyellerinin değerlendirilmesidir. Teorik çerçeve olarak realizm ve liberalizmin seçilmesinin nedeni, yazarın realist ve liberal temellere dayalı iletişim düzeninde çözümün yine bu teorilerin kavramları üzerinden tartışıımasının faydalı olacağı tezidir.

Neorealist ve neoliberal analizlerde sosyolojik ve normatif unsurların giderek daha fazla dikkate alınmasının gerekçesi yine küreselleşmeyle artan karşılıklı bağımlıııtır. Dolayısıyla bu teorik çalışmada, karşııklı bağımlılık ve reform kavramlarının, uluslararası iletişimin farklı analiz düzeylerini içeren (1) enformasyon toplumu, (2) kültürlerarası iletişim ve kamu diplomasisi ve (3) küresel yönetişim unsurları bağlamında betimsel karşılaştırmalı bir analizi yapılmaktadır. Uluslararası iletişim, uluslararası ilişkilerin şekillendiği ortam ve araçların tümünü içerir. Dolayısıyla birey-grup-devlet ve uluslararası sistem olmak üzere farklı analiz düzeylerini içeren unsurları bulunmaktadır. Bu farklı analiz düzeyleri ve uluslararası iletişimin hükümetlerarası ve/veya ulusötesi kulvarları, "enformasyon toplumu, kamu diplomasisi ve küresel yönetişim" başııklarında ele alınmaktadır. Realist ve liberal varsayımlara göre kavramlar incelenirken, neo-Marksist ekonomi politik ve sosyal konstrüktivist yorumsamacı yaklaşımların realizm ve liberalizmin üzerindeki etkilerine de yer verilmiştir.

Bu çalışmanın tezi, reform arayışı ve ortak çözüm çabalarında politika üretilmesi ve harekete geçilmesi gereken platformların yine eşitsizliğin kaynaklandığı ve sürdüğü "enformasyon toplumu, kamu diplomasisi ve küresel yönetişim" platformları olduğudur. Liberal düzenin insancıl yaklaşımlarla sürekli iyileştirilmesi ve hükümetlerarası olan ve olmayan, ulusaşırı ortamlar da dahil olmak üzere neorealist ve neoliberal politikalarla açıklanması ve gündemde tutulması, daha eşitlikçi ve adil bir düzen arayışında önemlidir. Reform ve çözüm çabalarında politika üretilmesi ve harekete geçilmesi beklenen alanlar; küresel bir enformasyon toplumu, düzen-adalet ikileminde adalet yönünde bir uluslararası kamuoyunun oluşturulması için kamu diplomasisi ve uluslararası kuruluşlar aracılığıyla daha etkin ve adil bir küresel yönetişimdir.

\section{KARŞILIKLI BAĞIMLILIK VE REFORM}

Uluslararası ilişkilerde liberal yaklaşımların küreselleşmenin temeli olarak gördükleri karşıılıklı bağımlıık, asimetrik ve eşitsiz bir yapı sergiler. Bu özelliğiyle liberal ve realist yaklaşımlar açısından karşııklı bağımlılık aktörler arasındaki güç dengesini yansıtmaktadır. Realist bakış açısına göre 
işbirliklerinde nispi kazançların dikkate alınması, uluslararası ilişkilerde sorunlara yol açabilmektedir. Karşıııkı bağımlıık, aktörlerin birbirlerinin siyasi, ekonomik ve sosyal davranışlarını dikkate alarak hareket etmeleri durumudur. Aktörler var olan şartlara göre, değişen kazançlara olumlu veya olumsuz yaklaşabilir. Daha az bağımlı olmak her durumda görece daha güçlü olmak anlamına da gelmemektedir. Bu nedenle liberal bakış açısına göre devletler ikili veya çoklu işbirlikleri yaparak ya da uluslararası örgütlere üyelik yoluyla bu asimetrinin olumsuz sonuçlarından kaçınır ve diğer aktörlerle daha yakın işbirliğine girmeyi tercih ederler.

Uluslararası ilişkiler her zaman realizmin vurguladığı ulusal çıkar mücadelesini yansıtan klasik güç dengesinden ibaret değildir. Ancak uluslararası iletişimin beslediği farklı işbirliği platformları ve işbirliklerinin kurumsallaşma şekilleri de var olan güç dengelerini yansıtmaktadır. Güçlü devletlerin uluslararası örgütlerin karar mekanizmalarında daha etkili olmaları ve buralarda asimetrik ilişkilerin gözlenmesi güç dengesiyle açıklanmaktadır. Ancak güç dengesi ve hegemonya gibi kavramlar dahi, sadece devletlerin temel aktör kabul edildiği bir düzen ile açıklanamamaktadır. Dolayısıyla karşııklı bağımlıık durumunun, liberalizmin çoğulcu bakış açısıyla ele alınması kavramın uluslararası ilişkileri açıklama kapasitesini artırmaktadır. Bağımlılık, aktörlerin dış politikada yalnızca kendi ulusal çıkarlarına dayalı olarak karar alamamaları durumudur. Bu durum bir çeşit egemenlik zafiyeti şeklinde eleştirilebilir. Diğer taraftan uluslararası iletişimin barındırdığı farklı düzeylerde etkileşim, devlet dışı aktörlerin etkilerinin çok arttığı bir ortamda devletlerin her durumda kendi kazançlarını hesaplayarak hareket etmelerini çok güçleştirmiştir. Bu durum ve uluslararası ilişkilerde neden tam olarak bağımsız hareket edilemediği, küreselleşmenin farklı boyutlarıyla açıklanmaktadır (Nye \& Welch, 2009, s. 351).

\section{Küreselleşme ve Karşılıklı Bağımlılık}

Küreselleşme kavramını kategorilere ayırarak açıklayan Joseph S. Nye ve David A. Welch, çevresel küreselleşmeye örnek olarak salgınları, tarım teknolojisindeki yeniliklerin yayııımını ve küresel ısınmayı verirken, askeri küreselleşmeyi küresel stratejik bağımlılık ile, toplumsal/sosyokültürel küreselleşmeyi kültürlerin, imgelerin, fikirlerin göç ve iletişim teknolojileri yoluyla yayılmasıyla ve siyasi küreselleşmeyi ise demokrasi ve uluslararası kurumların yaygın etkisiyle açıklamaktadır. Burada dikkat çeken, küreselleşmenin bu farklı kulvarlarının realist ve liberal paradigmaların her ikisinin varsayımlarını yansıtması ve ekonomik küreselleşmenin siyasi kulvar içine eklemlenmesidir. Bu noktada Nye ve Welch, 
küresel piyasaların bir boşlukta işlemediğini ve doğrudan güç dengesinden etkilendiğini belirterek bu duruma ekonomi politik bir gerekçe sunmaktadır. Finansal işlemler ve her alandaki uluslararası etkileşim, bilgi iletişim teknolojileri sayesinde gerçekleşmektedir. Bu nedenle veri transfer hızı önemli bir güç kaynağıdır, veriye önce ulaşan ilk işlemi gerçekleştirir (2009, s. 342-345).

Realizme yakın neoliberal yazarlar olan Robert O. Keohane ve Joseph Nye karşılıklı bağımlılığı devletlerin sınırlarını aşan uluslararası işlemlerin (para, mal, insan ve mesaj akışının) sonucunda oluşan "aktörler arasındaki karşlıklı etkiler" şeklinde tanımlamıştır (Rogerson, 2000, s. 416). Özellikle mesaj akışına, bilginin paylaşımı açısından dikkat çeken yazarlar, kompleks karşılıkı bağımlııı kavramıyla ulusötesi çoklu iletişimin/haberleşme kanallarının dış politikada gündem ve öncelik belirleme gücüne değinmişlerdir. Bu kavram ile devlet politikalarındaki gündem hiyerarşisinin değişken olduğuna dolayısıyla özellikle müzakerelere ve pazarlığa açık olan konulara ve askeri gücün karışmadığı alanlara dikkat çekmişlerdir (Keohane \& Nye, 1998, s. 83). 1990'ların sonunda yaptıkları çalışmalarında bilgi çağında kompleks/karmaşık bağımlılığı daha liberal ve kurumsalı bir çizgide incelemişlerdir. Neoliberal kurumsalcılık, neorealist ve neoliberal yaklaşımların sentezini yaparak, çoğulcu bir ortamda fikirlerin ve ortak çıkarların akışını ve dış politikaya nasıl yön verdiğini inceler. Kenneth S. Rogerson (2000, s. 432) bilgi bağımlılığı kavramıyla, bilgi akışının uluslararası ilişkilerde konu ve bağlamların alt yapısını oluşturan mekanizma ve süreçler olduğuna dikkat çekmektedir. Bilgi akışının parçası olamayanlar, başkalarının verdikleri kararların etki ve sonuçlarını yaşamaktadır. Oyunun kurallarını belirleyemezler.

Liberalizm açısından bakıldığında uluslararası iletişim; dış ticaretin yayılmasını, demokratik değerlerin uluslararası barışı sağlamaya yönelik etkilerini, işbirliğinin kurumsallaşmasında ortak norm ve kuralların oluşmasını ve ulusötesi ilişkilerin ulusal tercih ve çıkarların oluşumuna etkilerini belirleyen tüm ortam ve araçlardır. Yapısal anlamda güç dağılımı ve mikro düzeyde birimler/aktörler arasındaki etkileşimler uluslararası ilişkilere yön vermektedir (Nye J. , 1988, s. 251). Liberalizmin bu varsayımları zaman içerisinde evrilmiş, daha açıklayıcı bir çerçeve sunabilmek için realizm tarafından beslendiği gibi, bilgiye dayalı/bilişsel yaklaşım ile de desteklenmiş ve gelişmiştir. Özellikle çıkarların ve tercihlerin uluslararası arenada nasıl oluştuğuna ilişkin olarak bilişsel yaklaşımlar esin kaynağı olmuştur. Liberalizm, küresel kurumların (uluslararası örgütler, rejimler ve uluslararası anlaşmalar gibi) uluslararası aktörlerin etkileşimine ve davranışlarına "sosyalleşme ve öğrenme yoluyla" nasıl yön verdiğini bilişsel yaklaşımın kavramlarıyla açıklamaya çalışmaktadır. Devletler dış politikada uluslararası kurumları kendi itibarları, 
imajları için karşılıklılık prensibi çerçevesinde kullanırken, liberalizm tüm taraflar için mutlak fayda sağlayan sonuçlar elde edildiği argümanını savunur (Viotti \& Kauppi, 2012, s. 149).

İşbirliklerinin kurumsallaşmasında önemli yeri olan ortak norm ve kuralların oluşmasında ve benimsenmesinde "ortak değerlerin sosyal olarak inşasına" değinen konstrüktivist/inşacı teori ise neoliberalizmi besleyen bir başka yaklaşımdır. Dolayısıyla neoliberaller, gücün dağıımı gibi yapısal açıklamalar yerine, devlet dışı aktörlerin sayıca arttığı bir ortamda sosyal süreçlerle (kimlik ve çıkarların oluşumuyla) yapı ve aktörler arasındaki etkileşimi ve karşıııkı bağımlılığı açıklama eğiliminde olmuşlardır (Wendt, 1992, s. 391). Bu noktada uluslararası iletişimin ortam ve araçlarının nasıl kullanıldığı, bunlara erişim şekli, hızı ve düzeyi büyük önem taşır. Sosyokültürel yaklaşımlara, karşılıklı bağımlıık dışında enformasyon etiği ve uluslararası iletişimde reform konularında da ihtiyaç duyulmaktadır. Liberalizmin idealist özünü oluşturması beklenen ve dünya düzenini sorgulayan normatif tartışmalara eğilinmedikçe, bilgiye erişim konusunda uluslararası toplumu özellikle de gelişmekte olan ülkeleri memnun edecek çözümler üretilmesi zordur. Sosyolojik temellere dayalı normatif açılımlar bu kısır döngüyü kırmaya ve idealizmi bir nebze canlandırmaya ve evrensel/ortak değerleri tartışmaya fayda sağlayabilir. Ancak bu noktada da liberalizmin sunabileceği katkı tartışılırken, örneğin idealist Kantiyen yaklaşımın cumhuriyetlerden oluşan federal kozmopolit dünya toplumu yaklaşımının da bir çeşit hegemonyaya yol açabileceği yönüyle ya da doğru ve yanlışın herkes için aynı şekilde tanımlanmasının çok güç olduğu gibi gerekçelerle eleştirildiğini hatırlamak gerekir.

Neoliberalizm, daha adil bir uluslararası düzen ve gelişmekte olan ülkelerin kalkınma sorunlarına çözüm için dış faktörlerden çok, devletlerin iç politikalarına dikkat çeker. Aslında bu bakış açısı, liberalizmin dış politikayı iç politikanın devamı ve yansıması olarak görmesinden kaynaklanmaktadır. Iç̧ politikaya dayalı açıklamalar bir anlamda uluslararası kurumların barışı inşa etme, demokrasiyi güçlendirme gibi özgürleştirici etkilerini de azımsamakta ve ikinci plana atmaktadır. Dış faktörlere ve etkilerine rağmen iç siyasette siyasi elitlerin kendi çıkarlarına göre tercih oluşturup davranabilecekleri ve temel belirleyici olanın uluslararası kurumlar da olmadığı açıklanmaktadır. Tabi uluslararası iletişimde görüldüğü gibi bu kurumların da demokrasiyi ve eşitlikçi bir düzeni desteklememeleri senaryosu mümkündür. Üye devletler ve özel kuruluşlar asimetrik bir güç dengesinin bulunduğu durumlarda tarafsız davranmayıp, kendi çıkarlarına öncelik vermektedir. Demokratik ve katılımcı rejimlere sahip toplumların uluslararası liberal düzenden daha fazla faydalanabilmesi, iç ve dış siyasette haklarını koruyabilecek daha 
fazla olanağa sahip olmalarıyla ilişkilidir. Bu olanaklar arasında medya, bilgive erişim gibi iletişimin unsurlarını da gözden kaçırmamak gerekir.

\section{Liberal Reform Olasılığı}

Uluslararası iletişim düzeninde neoliberal bir reformun mümkün olabilmesi için demokrasinin inşasına ve serbest liberal ekonominin barışçıl etkilerine yönelik söylemlerin doğruluğuna ve yaygın etkisine inanmak gerekmektedir. Yapısal liberal yaklaşım önceki liberal yaklaşımlardan farklı olarak uluslararası siyasetin temel aktörleri olarak ulusal ve ulusötesi sivil toplumları görmektedir. Bu ekoldeki yazarlar, devletlerin politika ve davranışlarının bu grupların sosyal tercihlerine dayalı olarak oluştuğunu savunur (Moravcsik, 2010, s. 114). Dolayısıyla temel aktörler bireyler olup, rasyonel olan ise bireylerin işbirliği içerisinde ortak çıkarlarını gerçekleştirmesidir. Uluslararası düzende işbirliği veya çatışmayı belirleyen ya da işbirliğinin şartlarını çizen aslında sosyal şartlardır. Bu şartlar arasında karşıt düşünceler ve inançlar, yetersiz kaynaklar ve asimetrik güç dağıımı da sayılabilir. Liberal bir reform için aslında küreselleşmenin, aktörlerin kendi çıkarlarına kullanabilecekleri ulusötesi ekonomik, sosyal ve kültürel fırsatlar sunduğu tezi savunulmaktadır (Moravcsik, 2013, s. 711). Bu anlayışa göre, devletler tercihlerini belirlerken hem kendi içlerinde temsil ettikleri grupların çıkarlarını hem de karşııılı bağımlılık nedeniyle diğer ülkelerin ve toplumların çıkarlarını, maliyet ve kazançlarını dikkate almak durumundadır. Yumuşak güç ve kamu diplomasisi de bu nedenle önem kazanmaktadır. Diğer taraftan asimetrik güç dengesinde daha dezavantajlı olan grup ve devletler; sorunlarının ve beklentilerinin yeterince dikkate alınmadığının eleştirisini yapmaktadır. Bu ikilem, özel sektör kuruluşlarının iletişim sektörlerinde yaşanan sayıca artışı ve aralarındaki rekabet nedeniyle daha da içinden çıkılmaz bir hal almış, karmaşık kompleks bağımlıık onların lehine çalışmıştır.

Neoliberalizmin 2000'li yıllarda yaptığı sosyolojik çıkış, teorinin realizmden, liberal kurumsalcılıktan ve konstrüktivist yaklaşımdan ayrıştığını savunurken, asıl önemli olanın tercihlerin oluştuğu sosyal süreçler ve bu paylaşımların gerçekleştiği iletişim ortamları olduğunun altını çizmektedir. Bu yaklaşım, ulusal ve uluslararası düzeylerde iletişim ortam ve araçlarını temel platformlar olarak ilan ederken aslında küresel liberal reformun iletişim düzeninden başlaması gerektiğine de dikkat çekmektedir. Uluslararası ilişkilerde tercihlere dayalı açıklamalar, özünde değerler ve çıkarlar hakkında normatif tartışmalara kapı aralamaktadır. Liberal teorinin özgürleştirici tezlerini kısıtlayan ise rasyonellik 
varsayımıdır çünkü etik olan yerine rasyonel davranış arayışı, aktörleri mutlak kazanç arayışına yöneltmektedir (Arı, 2013). Teorinin özünden uzaklaşan bu bakış açışına göre etik davranmak ve adil olanı yapmak gibi bir öncelik söz konusu değildir. Ancak ortak değerlerin inşasına dönük yeni yaklaşımların bu rasyonalite ile devamı da mümkün değildir. Aslında rasyonel görülmesi gereken reformdur ve bunun için umut yaratan ve ortam hazırlayan da karşııklı bağımlııktır.

\section{ENFORMASYON TOPLUMU VE YENI MEDYA}

Uluslararası ilişkilerde, uluslararası iletişimin önemine dikkat çeken temel unsur bilgi devrimidir. Bilgi devrimi bilgisayarlara, iletişim teknolojilerindeki ilerlemelere dayanmaktadır. Elektriğin ucuzlaması nasıl kitle iletişimin ve yayıncılı̆ı̆ (radyo ve televizyon) artmasına yol açarak devletlerin merkezi otoritelerini arttırmış ise, 21. yy'da da internetin yaygın kullanımı ve ağlar devletlerin merkezi gücünü azaltmıştır (Nye \& Welch, 2009, s. 384). Bu şekilde devletin gücünü destekleyen kamu yayıncılığı yerini küresel medyanın etkisine bırakırken, küreselleşme beraberinde kimlik krizlerini de getirmiştir. Kamu yayıncılığı ulusal birlik duygusunu merkeze alan yaklaşımıyla ulus devletin siyasal kamu alanının ve ulusal kültürün odağı olmuştur. Oysa 1980'lerle beraber yaygınlaşan uluslararası yeni medya düzeni, en geniş tüketici kitlelerine ulaşmaya çalışırken ulusal sınırları engel olarak görmüştür (Morley \& Robins, 2011, s. 28-30). 1990'ların başında, Amerika Birleşik Devletleri (ABD) ve Sovyet Sosyalist Cumhuriyetler Birliği (SSCB) arasındaki Soğuk Savaşın ve iki kutuplu dünya düzeninin sona ermesiyle birlikte daha bütünleşik ve liberal ilkelerin yaygınlaştığı dünyanın daha demokratik ve barışçıl olup olmadığı tartışılmaya başlanmıştır.

Yeni medya düzeni, liberalizmin özgürleştirici tüm vaatlerine rağmen küresel bir hegemonyaya dönüşmüştür. Küresel şirketler, üretim, dağıtım ve iletimde tek kaynak durumuna gelmeye çalışırken, telekomünikasyonda yöndeşme; eğlence ve bilgi hizmetlerinin aynı mecralara taşınması bu hedefe hizmet etmiştir. Bu bağlamda, kamusal iletişimin stratejisinin ne olması gerektiği gelişmiş ülkeler açısından da önemli bir sorun haline gelmiş, küreselleşme karşısında yerele inme ihtiyacı gündeme taşınmıştır. Örneğin Avrupa Birliği (AB) için öncelikli iletişim stratejisi, Amerikanlaşma tehdidine (CNN haber ağı, gişe rekorları kıran filmler gibi) karşı yerel olanı korumak ve aynı zamanda Avrupa kimliğini güçlendirmek olmuştur (Morley \& Robins, 2011, s. 38-39). Avrupa kökenli olmayan programlara uygulanan korumacı realist kota politikası bu stratejiyi yansıtır. Kamu yayıncılığı konusundaki benzer 
önlemler aslında uluslararası iletişimin kamusal ve özel alanlarında (hem kamu diplomasisi hem de yeni küresel medya düzeninde) küreselleşmenin siyasal, ekonomik ve sosyokültürel boyutlarını ve devletlerin yumuşak güçlerine olan etkilerini yansıtmaktadır. İnternetin sağladığı sınırsız iletişim olanaklarını denetlemek oldukça zor ve maliyeti de yüksektir.

Realizme göre, aslında bilgi devrimi en çok devletlere hizmet eder, bu durumu bilgi devriminin güçlü devletlere daha çok yarar sağlaması şeklinde de okumak mümkündür. Bilgi devriminden tüm devletler aynı oranda ve seviyede etkilenmemiştir. Sayısal bölünme/eşitsizlik, teknolojinin yayılma ve özümsenme hızı ve kapasitesi değiştikçe etkili olmakta ve eşitlikçi bir paylaşımdan bahsetmek gelişmiş ülkeler arasında bile mümkün olamamaktadır. Bilgi devriminin farklı etkilerinden bahsederken, uluslararası iletişimi ilgilendiren birkaç faktör sözkonusudur. Bunlardan ilki büyüklüktür, büyüklük önemlidir çünkü büyük eğlence endüstrileri, kuruluşları içeriğin üretimi ve dağıtımında ölçek ekonomisinden yararlanmaktadır. Aslında devletlerin yumuşak gücü de (oluşturdukları çok yönlü çekim ve etki alanı) bu sektörlerden (örneğin film endüstrisi ve televizyonculuktan) beslenir. Uluslararası iletişimi etkileyen ikinci faktör ise sermayedir, çünkü yeni bilginin üretimi yatırım gerektirmektedir. Her sektörde öncü konumunda olanlar büyük avantaja sahip olmaktadır. İnternette İngilizcenin hegemonyası, bu duruma en tipik örnek olarak gösterilebilir. Sermaye ve güce dikkat çeken bir diğer durum ise askeri teknolojilerin iletişim teknolojilerindeki yeridir. Örnekleri zaman içerisinde değişmekle birlikte, GPS (küresel konumlandırma sistemi), uydu görüntüleri gibi eski askeri teknolojilerin sivil topluma kullanılmak üzere sunulması stratejisi değişmemektedir (Nye \& Welch, 2009, s. 388-390).

\section{Enformasyon Toplumu ve Kapitalizm}

Yapısal ve ekonomiye dayalı analizler yapan Marksist yaklaşım ve daha aktör temelli analizler sunan neo-Marksist bağımlılık teorileri için enformasyon/bilgi toplumu, kapitalizmin içinde bulunduğu farklı bir evredir. Manuel Castells'e göre enformasyon toplumu bilginin toplumsal ilişkileri belirlediği, üretimin ham malzemesi, üzerinde çalışılan kaynağı ve tüketim metası olduğu bir evresidir. Bu yapı içerisinde, bilginin bulunduğu ve aktarıldığı ortam ise yeni medyadır. Bu toplumsal yapılanmada, üretim araçlarının mülkiyetine dayalı sınıfsal bir çatışma yerine, bilgiye sahip olanlarla olmayanlar arasında çatışma bulunur (Timisi, 2003, s. 98). Yeni medya, kitle iletişim araçlarıyla birlikte, güç ilişkilerinin şekillendiği ve kabul edildiği yeni bir ortamı oluşturmuştur (Castells, 2007). Yatay ve etkileşimli ağlar; 
internet, mobil iletişim, sayısal medya ile bireylerin kamusal alana katılımını arttırmakta ve ortaya çıkan "kitlesel öz iletişim" yeni güç ilişkilerini ve karşı güç oluşumlarını beslemektedir. Sosyolog Castells, karşı güç kavramıyla, bir aktörün toplumdaki kurumsallaşan güç ilişkilerine karşı koyma ve hatta meydan okuma kapasitesini açıklamaktadır. Gelişmekte olan ülkelerin ihtiyaç duyduğu kapasite budur. Teknoloji, iletişim ve güç ilişkileri arasındaki etkileşim; birbirine karşıt değer ve çıkarların dolayısıyla sosyal aktörlerin çatışmasını içermektedir. Ağ toplumunun omurgasını oluşturan sayısal teknolojiler/yeni medya, tıpkı kitle iletişim ortam ve araçları gibi bu çatışmaya açık bir arenadır. İletişim ve güç arasındaki ilişki liberal yapısalcıların yaptığı gibi sosyolojik olarak ele alındığında; küreselleşmenin devletlerin siyasi ve ekonomik karar mekanizmalarını etkileyen boyutlarının, medya şirketlerinin birbiriyle küresel rekabetinin ve kültürel farkılıkların (örneğin "bireyci ve toplulukçu" toplumsal yapıların etkileşiminin) farklı toplumlar için dikkate alınması gerekmektedir (Castells, 2007, s. 239).

Ağ toplumunda ekonomik üretim bilgi kaynaklarına erişime dayalıdır. Bu nedenle neoMarksistlere göre yeni medya düzeni kapitalist üretimin temelini oluşturmaktadır. Liberal yaklaşıma göre ise bilgiye ulaşabilen birey, kendinin daha fazla farkındadır ve hatta üretim süreçlerinin değişimiyle evinden çalışabilecek, üretime katkı sunacak ve özgür zamanının artmasıyla sivil topluma katılım ortamları da çoğalacaktır. Dolayısıyla teknolojik ilerlemeyi; demokrasi, seçme şansı ve çoğulculuk olarak okuyan liberal yazarlar gelecek konusunda ağ toplumunda daha iyimserdir (Timisi, 2003, s. 100). Her ne kadar liberalizm ağ toplumunun bireyi özgürleştiren etkisini vurgulasa da sayısal eşitsizlik bu iyimserliği gölgelemektedir. Bu durumda yeni medyanın karşııklı bağımlılı̆̆ı, sosyal dönüşümü, sosyal hareketleri, aktivizmi destekleyen teknolojik ve sosyolojik unsurları, adil iletişim düzeni konusunda yeni umutları da beslemektedir. Bilgi kaynaklarının artması, siyasi elitlerin gündem belirleme ve küresel şirketlerin eşik bekçiliği rollerinin azalması beklentiler yaratırken, tabi bu ortamların ne ölçüde bilinçli ve etkin kullanılabileceği konusunda endişeleri de doğurmaktadır (Castells, 2007, s. 257). Sayısal iletişimde medya yakınsaması; bilişim, telekomünikasyon ve medya sektörünün tek bir endüstriye dönüşümü anlamına gelmektedir. Uluslararası medya kuruluşlarının büyümesi liberal küresel ekonominin bir gereği olarak düşünülürken, yeni medyanın kamuoyunu iletişim süreçlerinde içerik üreten ve paylaşan aktörler haline getirmesi, demokrasinin temel unsurlarından biri olarak kabul görmektedir (Timisi, 2003, s. 101102). Yeni iletişim teknolojileri sayesinde bilgiye eş zamanlı ulaşabilen bireylerin, ulusötesi bir kamusal alanı ve küresel bir sivil toplumu genişlettiği savunulmaktadır. Ancak içeriklerin kimler tarafından, nasıl 
hazırlandığı, dolaşıma sokulduğu ve bunların tüketilmesinin sonuçlarının neler olduğu da değerlendirilmesi gereken etik sorunlar arasındadır.

\section{Yeni Medya ve Etik}

Yeni medyanın e-ticaret, e-öğrenme, siyasal iletişim gibi alanlarda artan kullanımı, küreselleşme tarafından beslenen bağımlııkları daha kompleks hale getirmektedir. Bilginin küresel yayılımı toplumsal ağlar, sivil toplum kuruluşları (STK'lar) aracılığıyla gerçekleşirken sosyal medya kamusal alan özelliği kazanmış, kitle iletişim araçlarının ise eğlence amaçlı kullanımı artmıştır. Ancak iletişim ortam ve araçlarının kullanımı; coğrafya ve ülkelere göre farklılıklar göstermektedir. Özellikle teknolojiye erişim ile ilgili, sayısal eşitsizlik, sayısal uçurum gibi dengesizlikler; ülkelerin sosyo-ekonomik kalkınma ve gelişmişlik düzeylerini dikkate almayı gerektirmektedir. UNESCO enformasyona erişim ve iletişimde küreselleşmenin etkileri konusundaki tartışmaların yapıldığı temel uluslararası platformdur. Genel enformasyon etiğinin yanısıra, enformasyon zenginleri ve yoksulları, kamusal ve özel mal olarak enformasyon, sanal uzayda enformasyon, internette gizlilik ve güvenlik gibi konular temel tartışma konularını oluşturmaktadır. Enformasyon etiği, yeni telekomünikasyon teknolojilerine erişimde eşitlik, adalet ve karşılıklı saygı gibi değerleri içeren bir kavramdır. UNESCO INFOetik forumlarında gündeme gelen diğer başlıca konular ise; gelişmekte olan ülkeler için telif hakları muafiyetleri, ifade özgürlüğü ve internette mahremiyet gibi konulardır (Binark \& Bayraktutan, 2013, s. 27-31). Gelişmiş ülkelerden daha az gelişmiş ülkelere bilgi akışında; üretim evresi, iletişim donanım ve yazılımı ve dağıtım evresi açısından farklı bağımlııklar söz konusudur (Mowlana, 1985, s. 14). Bu durumda kaynak ve alıcı arasındaki kültürel, sosyoekonomik uzaklık, iletişimin her bir unsurunun kaynak ülke tarafından kontrol edilebileceğini göstermektedir. Iletişimde özerklik ancak bir ülkenin donanım ve yazılım açısından olduğu kadar, üretim ve dağıtım araçları yönüyle de kendi kendine yeterli olduğunda sağlanabilir.

Uluslararası iletişim düzeninden kopmadan bu potansiyele sahip olabilmek, gelişmekte olan ülkeler için kolay değildir. Medya düzeninden faydalanma konusundaki karşılaştırmalı çalışmalarda gelişmişlik düzeyi kadar siyasal kültür de dikkate alınmaktadır (Siebert, Peterson, \& Schramm, 1956). Farklı ideoloji ve siyasal kültürlerin, toplumların uluslararası iletişime katılma derecesini ve iletişim modellerini belirlediği tezi, medya sistemleri üzerine yapılmış olan çalışmalarda görülmektedir (Hallin \& Mancini, 2004). Soğuk Savaş döneminden itibaren küresel medya kuramları, ülkelerin medya sistemlerini 
ve iletişim düzenlerini, özünde realist ve/veya liberal yaklaşımlar olarak sınıflandırmaya çalışmıştır. Bu bağlamda, devlet merkezli/tekelci yaklaşımlar gibi Marksist ve neo-Marksist yaklaşımlar da (uluslararası iletişim düzenine yönelik ekonomi politik eleştiriler) realist kuram altında değerlendirilebilir. Klasik liberal düşünceye göre şekillenen bağımsız özgür medya yaklaşımları zaman içerisinde yerini daha kolektivist görüşlere bırakırken, internet ile birlikte farklı düzeylerde küresel yönetişim kavramı da tartışılmaya başlanmıştır. Farklı modellerin uluslararası iletişimi açıklama kapasiteleri, bilgi/haber akışının var olan siyasal ve ekonomik yapılardan ve kurumlardaki güç dağıımından etkilenmesinden kaynaklanmaktadır. P. Humphreys (2012), iletişim modellerindeki sınıflandırmacı yaklaşımı eleştirerek, Hallin ve Mancini'ye yanıt verdiği çalışmasında, toplumların farklı siyasal ve sosyokültürel özelliklerinin iletişim modellerinde belirleyici olduğuna dikkat çekmiştir. Teknolojiyi tarihten, içinde geliştiği siyasi ve ekonomik koşullardan bağımsız olarak ele almak ve teknolojiyi toplumsal değişimin temel kaynağı ve yeni iletişim düzenine geçiş olarak kabul etmek bu derin konuyu basite indirgemek olacaktır (Atabek, 2013, s. 175).

Enformasyon akışından etik olarak herkesin eşit oranda yararlanması gerekirken bu akışın bazı grupların bilgisini daha çok artırması enformasyon gediği/uçurumu kavramıyla açıklanmıştır (McQuail \& Windahı, 2010, s. 153). Daha az ayrıcalıklı grup ile ayrıcalıklı grup arasındaki uzaklı̆ın azalması, ancak enformasyonun sınırlı olduğu durumlarda gerçekleşebilirken, ayrıcalıklı grup enformasyon arayışını sürdürürse söz konusu aranın kapanması daha da zordur. Bu durum aslında herhangi bir toplumda eğitimli ve daha az eğitimli gruplar arasında yaşanabildiği gibi uluslararası iletişimde gelişmiş ve az gelişmiş ülkeler arasında yaşanmaktadır. Bilgi iletişim teknolojilerindeki ilerlemelerin sosyal değişim ve dönüşüm üzerinde doğrudan etkili olmadığı, bu süreçlerin siyasi olduğu ve farklı çıkar gruplarının etkisiyle gerçekleştiği de gözden kaçırılmamalıdır (Meyer, 2005). Örneğin medya kuruluşlarının yatay büyümesi bir çarpan etkisi sergiler çünkü medya sahipliği yayın içeriklerini de etkilemektedir. Dolayısıyla enformasyon toplumunda arttığı gözlemlenen etkileşimin, demokrasi adına sihirli bir değnek olarak görülmemesi, hangi bilginin kim tarafından ne kadar tüketildiğine ve hangi etkileri doğurduğuna dikkat edilmesi gerekmektedir.

\section{KÜLTÜRLERARASI ILETiŞiM VE YUMUŞAK GÜç}

Kültürlerarası iletişim, toplumların birbirine kültürel uzaklığının iletişimleri üzerindeki etkilerinin incelendiği bir çalışma alanıdır. Kültürlerarası iletişimi etkileyen faktörler, Asker Kartarı tarafından (2014, 
s. 227); değerler ve normlar, toplumsal senaryolar ve roller, etnomerkezcilik, belirsizlik, kaygı ve önyargılar şeklinde sıralanmıştır. Farklı kültürlerden bireylerle ve gruplarla iletişim kurmak, yaşanması beklenen belirsizlik nedeniyle kaygı yaratabilmektedir. Ancak bu kaygının ne kadar hissedildiği, toplumsal ve bireysel özelliklere göre farklılıklar göstermektedir. Geert Hofstede araştırmalarında kültürel özelliklerin bireylerin ve toplumların iletişim alışkanlıkları üzerindeki etkilerini incelemiştir. Kültürel Boyutlar Kuramı ile, değerlerin davranışlar üzerindeki etkilerini incelemek üzere değerlerin kategorilere ayrıldığı altı boyutlu bir ölçek geliştirmiştir. Iletişim alışkanlıkları her bir boyutun iki aşırı uç arasında yerleştiği yere/puana göre değerlendirilmektedir.

Tıpkı iletişim süreçlerinin kültüre ve dile dayalı olması gibi, kültürün gelişimi ve değişimi de iletişime dayalıdır. Hofstede $(2015$, s. 2) kültürü tanımlarken beynin toplumsal olarak programlanması metaforunu kullanmıştır. Dolayısıyla bu programlama, bir grubun üyelerini diğerlerinden ayırt etmeye yarar. Ortak değerlerin toplumu oluşturan bireylerin akıllarına kodlanmasında erken çocukluk dönemi ve çevresel faktörler önemlidir. Oysa kültürlerarası iletişim için gereken ortak davranış ve uygulamalar ise yaşamboyu değişebilecek ve öğrenilebilecek bilgilerdir. Hofstede, farklı kültürlerden bireylerin, örneğin birlikte çalışabilmek için ihtiyaç duyduklarının ortak değerler değil, ortak davranış şekilleri ve uygulamalar olduğunu vurgulamaktadır. Yıllar içerisinde "değerler anketinin" uygulandığı kurum ve işletmelerde toplanan veriler, kuramın aşağıdaki altı boyutunu şekillendirmiştir:

a. Güç aralığı (mesafesi) ve sosyal hiyerarşi toplumların her toplumda bulunan eşitsizliğe yaklaşımları ve bunu nasıl yönettikleriyle ilgilidir.

b. Bireyin veya toplumun ortak yaşamda ön planda olması başkalarına bağımlı olma durumu ve derecesiyle ilgilidir.

c. Belirsizlikten kaçınma, toplumların bilinmeyenle başa çıkma becerisiyle ilişkilidir.

d. Toplumsal cinsiyete göre davranışlar, maskülen ve feminen toplum ayrımı duygusal olarak cinsiyet rollerinin toplum içinde benzerliği ve farklılı̆ına dayalıdır.

e. Uzun vadeli/kısa vadeli oryantasyon toplumun zaman perspektifini, geleceğe bakışını ve geçmişe bağılık durumunu yansıtır.

f. Toplumsal yaşamda serbestliğe karşı sınırlama ise toplumun doğal güdülerin ve insani ihtiyaçların giderilmesine yaklaşımı ve bunlarla başa çıkılmasına yönelik tutumlarla ilişkilidir (Hofstede, 2015, 5. 4-5). 
Kültürlerarası çalışmalarda ülke karşılaştırmalarının yapılmasına olanak tanıyan bu ölçek, daha çok uluslararası işletmecilik ve iletişim alanlarındaki çalışmalarda referans alınmaktadır. Bu çalışmalar, toplumların bu ölçekte nerede bulunduklarına göre kültürel uzaklığın yani kültürler arasındaki benzerlik ve farklılığın derecelendirilerek yorumlanmasını içermektedir. Kültürel farklılıklar iletişim yöntem ve şekillerini belirlemektedir. Örneğin bireylerin daha ön planda olduğu toplumlarda iletişim doğrusaldır, oysa kolektivist ve topluluğun önde geldiği bir toplumda, mesaj önce gönderen grubun içinde değerlendirilir ve sözlü olmayan unsurlar da devreye girer. Diğer taraftan mesajı alan grup da kendi içinde mesajı değerlendirecek ve süreç daha kompleks hale gelecektir. Uzun vadeli oryantasyona sahip toplumlarda yazılı mesajlar tercih edilirken kısa vadeli oryantasyonu yüksek toplumlar sözlü iletişimi ve sosyal medyada temsili daha çok tercih ederler. Güç mesafesinin fazla olduğu toplumlarda otoriteye karşı duyulan saygı ve kabullenme iletişim şekilleri ve alışkanlıklarını da etkilemektedir. Hofstede'ye göre (2015, s. 11) böyle toplumlar daha çok TV izleyip daha az gazete takip ederler ve içerikleri çok sorgulamazlar. Belirsizlikten kaçınmanın yüksek olduğu toplumların bilinmeyene, tanıdık olmayan şeylere karşı toleransı azdır ve değişime uyumları düşüktür. Yeniliklere karşı direncin fazla olduğu toplumlarda buluş ve inovasyon sayılarının az olduğu ve internet kullanımının da düşük olduğu gözlenmektedir. Hofstede'nin verdiği bu örnekler referans alınırken temkinli olunmalı ve genellemelerden kaçınılmalıdır. Farklı toplumların, bireylerin iletişim ağlarında ne kadar etkin olduklarının, hangi iletişim ortam ve araçlarını tercih ettiklerinin belirlenmesinde kültürel farklılıkara dikkat çeken bir çerçevedir.

Kültürlerarası iletişimde barışçı veya çatışmacı yöntem/dil kullanılabilir ancak üç temel unsur dikkat çekmektedir; (1) kültürel farklııkların farkında olmak, (2) kültürler hakkında bilgi sahibi olmak ve (3) farklı değerlere sahip bireyler ile iletişim kurma becerisine sahip olmak ve onlarla ortak davranış şekilleri oluşturmak (Hofstede, 2015, s. 12). Bunlar bireyler için geçerli olduğu gibi toplumlar için de söz konusudur. Kültürlerarası (ulusötesi) iletişim konusundaki bilinç ve hassasiyet günümüzde realist ve liberal bakış açısıyla kamu diplomasisini, devletlerin uluslararası kamuoyu üzerindeki yumuşak güçlerini arttırma isteklerini arttırmaktadır. Uluslararası ilişkilerde artan aktör sayısı; uluslararası örgütlerin, medya şirketlerinin, STK'ların, çıkar gruplarının ve bireylerin de kamu diplomasisinde rolünü artırmıştır. Bu durum liberal anlayışa göre, kamuoyunun artan rolüne ve uluslararası düzeyde bir toplum anlayışına sahip olunmasına dayanır. Uluslararası siyasette klasik realist anlayış, devlet adamlarının, diplomatların 
mevkidaşlarıyla ilişkilerinde ulusal çıkarlara dayalı ve rasyonel davranmaları anlayışına dayanıyordu. I. Dünya Savaşı'na kadar daha realist çizgide izlenen diplomasi, liberal yaklaşımın bireyi ve kamuoyunu ön plana çıkaran anlayışıyla eleştirilmeye başlanmıştır. Liberal demokrasi, kamuoyunun iç politika yanında dış politika süreçleri hakkında da bilgilendirilmesi gerektiğine dikkat çekmiştir. Dış politika süreçlerinde; sosyoekonomik elit, siyasal elit, medya, kanaat önderleri ve kamuoyunun kararlara etkileri analiz edilmeye ve farklı hedef kitlelere nasıl ulaşılabileceği incelenmeye başlanmıştır.

\section{Kültürel Farkındalık ve Kamu Diplomasisinin Yükselişi}

Kamu diplomasisi aslında halkla ilişkiler ile ortak yönler taşımaktadır. Hedef kitlesi uluslararası toplum olan bu diplomasi de temsil, diyalog ve danışmanlık dinamiklerine dayalı olarak uluslararası kamuoyuna yönelik yürütülür. Bu çerçevede temsil, kullanılan dil ve görüntülü medyayı; diyalog, yürütülen müzakere ve arabuluculuk süreçlerini ve danışmanlık/akıl hocalığı ise kampanya planlama veya kriz yönetimi gibi danışmanlık süreçlerini ifade etmektedir (Demir, 2012, s. 260). Uluslararası halkla ilişkilerin bu temel araçları kültürlerarası iletişimin ve kamu diplomasisinin temel unsurlarıdır. İtibar ve imaj yönetimi açısından bırakılan izlenim önemlidir, itibarın ölçülmesi ve gerektiğinde düzeltilmesi ve markalaşma konularında planlı ve özenli bilimsel analizlerin yapıldığı araştırmalar önemlidir (Demir, 2012).

Kamu diplomasisine duyulan ihtiyaç, kompleks karşııklı bağımlııklar sonucunda dünya siyasetinde hükümetlerin, kendi halkları yanısıra uluslararası kamuoyunun desteğini kazanma isteğine bağlı olarak artmıştır. Illetişim teknolojilerinin ulusal sınırları daha geçirgen kılan özellikleri ve STK'lar gibi ulusaşırı aktörler ile artan kültürlerarası/bireylerarası iletişim artık halkla ilişkilerdeki gibi planlı ve sürekli girişim ve kampanyaları gerektirmektedir. Bu durumu neoliberal J. Nye $(2004,5$. 5) uluslararası siyaset literatüründe yumuşak güç kavramıyla açıklamıştır. Uluslararası toplum tarafından kabul gören ortak siyasal değerleri temsil ettiği düşünülen ve özenilen devletler, siyasi gündemi kültür, ideoloji ve bunların kurumları aracılığıyla belirlemektedir. Yumuşak gücün literatürdeki bir diğer kavram olan hegemonya ile ilişkisi aslında cezbeden gücün yarattığı etki alanına gösterilen rızadan kaynaklanır. Demokrasi, insan haklarının korunması gibi temel değerler ile başlayan rıza ve onay süreci, yumuşak güce sahip devletlerin siyasi gündemi belirleyebilme kapasitelerini besler. Algı ve imaj yönetiminde medya, şirketler, uluslararası kuruluşlar, epistemik bilgi toplulukları, aktivistler gibi aktörler de paydaş rolündedir. Kamu 
diplomasisi iletişim düzeninde reform için de aktif kullanılabilecek bir yöntemdir. Liberal yaklaşımların belirttiği gibi tercihlerin sosyal süreçlerle oluşumunda artan kitlesel öz iletişim, gelişmekte olan ülkelerin seslerini daha fazla duyurabilecekleri ve destek için uluslararası kamuoyunun dikkatini çekebilecekleri ortamlarda gerçekleşmektedir. Dolayısıyla yeni politikalar için yumuşak güç oluşturulmasında mesajlar, yeni medya ile kitlelere, uluslararası kamuoyuna ulaştırılabilir. Bunu uluslararası kuruluşlar enformasyon etiğine yönelik kampanya ve çalışmalarında yapmaktadır. Benzer stratejik iletişim kampanyaları, sadece kitle iletişim araçlarının değil, yeni medyanın kullanımını ön plana çıkarmıştır. Bu durum da Marc Prensky'nin (2001) tanımıyla yeni medyaya (sayısal teknolojilerin var olduğu ortama) doğan nesillere yani dijital yerlilere ulaşmanın yolu yeni medya ortamlarından geçmektedir. Zaten sadece kitle iletişim araçlarının kullanılmasıyla, analog dünyaya doğan dijital göçmenlere ulaşıımış olacaktır.

\section{KÜRESEL YÖNETIŞiM VE REJIMLER}

Uluslararası iletişim düzeninin incelenmesinde kullanılan liberal kavramlar arasında rejimler ve yönetişim de sayılabilir. Rejimlerin oluşması ve sürdürülmesi açısından uluslararası kuruluşlar/örgütler önemli rol oynamaktadır. Uluslararası iletişimde koordinasyon ihtiyaçlarının giderilmesine ve işbirliklerinin kurumsallaşmasına ilişkin yapılan anlaşmalara ilk örnek Uluslararası Telekomünikasyon Birliği'ni kuran anlaşmadır. Ayrıca ilk uluslararası örgüttür. ITU kısaltmasıyla anılan birlik, Uluslararası Telgraf Birliği adıyla 1865 yılında telgraf sistemlerinin uyumlu hale getirilmesi amacıyla kurulmuştur (Özen, 2019, s. 10). Bu ihtiyacı, radyo frekansları, uydu ve bilgisayar dolayımlı iletişim konularındaki işbirliği ve ortak koordinasyon ihtiyacı takip etmiş̧tir. Uluslararası iletişimde başlayan bu işbirlikleri, liberal fonksiyonalist (işlevselci) teori ile açıklanmıştır. Bu teoriye göre teknokratların ulusötesi işbirlikleri, devletler arasında koordinasyonu sağlamak için gerekli şarttır. Bu yaklaşım zaman içinde liberal ekonomik düzenin gelişimiyle birlikte kolektif bilişsel süreçler, aktörler arasında ortak anlayışların oluşması ve bilgi topluluklarının (epistemik toplulukların) rejimlerin oluşumuna etkisi tezlerine evrilmiştir. Realist yazarlar bu kurumsallaşmayı, devletlerin belli alanlardaki zorunlu koordinasyon ihtiyacı ve talebi (hatta ortak çıkarı) olarak değerlendirirken, liberal yazarlar devlet dışı aktörlerin uluslararası iletişimin önemli aktörleri olmalarından hareketle bu durumu daha çoğulcu ve işbirlikçi bir anlayışla ele almışlardır. Hem realist hem de liberal rejim teorisi yaklaşımları, uluslararası rejimlerde düzeni sağlayan, bağımlııı ilişkilerini etkileyen yönetim düzenlemeleri bulunduğunu ve "ortak ilke, norm, karar verme mekanizmaları 
ve prosedürler" ile sürekliliğin ve istikrarın sağlandığını açıklamaktadır (Ruggie, 1975; Krasner, 1982, s. 185).

Realist ve liberal yaklaşımlar, işbirliklerinin kaynağı konusunda farklı açıklamalar sunar. Örneğin realist yaklaşım devletlerin çıkar ve ihtiyaçları üzerinde dururken, liberal anlayış devlet dışı aktörlerin etkileri ve özellikle piyasa ekonomisindeki rekabetin ve beklentilerin altını çizer. Realistlere göre, hegemon bir devletin rejimdeki varlığı, düzenin (istikrar) ve işbirliğinin sağlanması ve sürdürülmesinde temel itici güçtür. Bu nedenle zayıf devletler, kendi istekleri dışında işbirliği normlarına göre hareket etmek zorunda kalabilir. Liberaller ise işbirliklerinin sürdürülmesinde ortak kurumların varlığına ve etkisine işaret ederler. Özellikle karşııkı bağımlıık teorisi, piyasaların işlem ihtiyaçlarının iletişim rejimleri tarafından yerine getirildiğini açıklamaktadır. Rejim çatısı altındaki çok tarafı işbirliği ve koordinasyon (örneğin radyo frekanslarının tahsisinde olduğu gibi) ikili anlaşmalara göre işlem maliyetlerini çok daha fazla düşürerek taraflar için kazançlı olmaktadır. Stephen D. Krasner, realist bir yaklaşımla iletişim rejimlerini incelediği çalışmasında, rejimlerin oluşumu ve uğradıkları değişimi devletlerin güç kapasitelerindeki değişime bağlamıştır. Güç dağıımının asimetrik olduğu alanlarda rejim oluşamayacağını vurgulayarak radyo yayıncılığı ve uzaktan algılama sistemleri konusunda bir rejim bulunmadığını belirtmiştir. Bu alanlarda güçlü devletlerin avantajı olduğunu ve kuralları tek taraflı olarak, ilke ve normlar üzerinde uzlaşı olmadan belirlediklerini açıklayan realist yazar, güç dağılımının daha simetrik olduğu ve tarafların koordinasyon sorunu yaşadığı durumlarda örneğin telekomünikasyon alanlarında, rejimlerin mümkün olduğunu belirtmiştir. Buna örnek olarak gelişmekte olan ülkelerin ITU üyelikleri ve oy hakları çerçevesinde telgraf, telefon, televizyon yayıncılığı gibi konularda kararlara etki edebilmelerini vermektedir (1991, s. 337). Ancak telekomünikasyon alanında da özel kuruluşların sayıca artması ve üyelik talepleriyle bu düzen değişmektedir.

Uluslararası iletişim rejimleri, özellikle 1980'li yıllardan sonra, artan şekilde sektörün liberalleşmesinden etkilenmiştir. Bu durumu iletişim teknolojilerinin, özellikle ABD'de yerleşik devlet dışı/özel aktörlere kazandırdığı etki alanı ve güç ile açıklayan realist yaklaşım, rejimin tekelci ulusal yapıdan çıkarak daha rekabetçi piyasa şartlarına dayalı bir özellik kazandığını vurgular. Devlet dışı aktörler; çok uluslu şirketler, STK'lar, lobiler gibi aktörler, rejimlerin oluşmasında devletleri ikna etmektedir. Bu eğilim öncelikle ABD, Birleşik Krallık ve Japonya'da kendini göstermiştir. Ulusal politikaların değişmesini realistler, inovasyonun güç kapasitelerine etkisi olarak değerlendirir (Krasner, 
1991, s. 356). İletişim sektörünün hızlı liberalleşmesine dikkat çeken realist yazarlar aslında küresel ekonominin bu düzeni belirlemesini (ekonomik küreselleşmeyi) açıklarken liberal yazarlara da yakın durmaktadır. Uluslararası ilişkiler disiplininde özellikle 1990'ı yıllardan itibaren neorealist ve neoliberal alanyazının birbirinden ayırt edilmesinde zorlanılmasına ve kuramların temel yaklaşımlarında dikkat çeken yakınlığa uluslararası iletişim konusundaki söylemler ve açıklamalar da örnek oluşturmaktadır.

Uluslararası ve ulusal düzeylerde liberal politikalar ve artan özelleştirme, internetin küresel yönetişiminde kendini daha fazla hissettirmektedir. Iletişim teknolojilerindeki gelişmelerin; kitlesizleştirme, yöndeşme ve bireyi merkeze alan doğası, iletişim ortam ve araçlarının yönetişiminde farklı yollar izlenmesini gerektirerek ayrı rejimlerden bahsedilmesini de güçleştirmektedir. Ancak özellikle telekomünikasyon rejimini internetin küresel yönetişiminden ayrı tutma eğilimi güçlenmiştir. J. P. Singh'e (2010, s. 1-3) göre, uluslararası iletişim rejimleri uluslararası ticaretin gerçekleşmesine ortam sağlayan birtakım sosyalleşme süreçleridir. Bu rejimler; telekomünikasyon (uydular, radyo-televizyon yayıncılığı, keşif-gözetleme, ses ve veri mesajları gönderme), internetin küresel yönetişimi ve elektronik ticaret rejimi olarak sınıflandırılabilir. Rejimlerin ortak normları bilgi akışını serbestleştirirken; kurallar uluslararası anlaşma, konferans ve örgütlerce belirlenmiştir. Karar verme prosedürleri ise gayri resmi görüşmeler, uluslararası hukuk, uluslararası ajanslar ve çatışma çözümü/tahkim için yapılandırılmış kuruluşların kararları yoluyla sağlanabilmektedir. Uluslararası iletişim rejimlerinin analizinde devlet gücüne dayalı realist yaklaşım; karşılıklı bağımlılık ve küresel piyasa ekonomisine dayalı liberal yaklaşım ve küresel yönetişimin altyapısını oluşturan bilgi topluluklarının (mühendisler, yazılımcılar, iktisatçılar, finansçılar gibi) tümüne ihtiyaç duyulmaktadır. Ortak bilişsel süreçlere, gelişmekte olan ülkelerden daha fazla katılım sağlanması, asimetrik güç ilişkilerinin uluslararası iletişim üzerindeki eşitsiz izlerinin silinmesine fayda sağlayacaktır. Ancak ortak iradenin bu yönde gelişimine realist ve liberal kaygılar engel olmaktadır. Küresel bilgi toplumu çağrısının sözde kalmaması için, gelişmekte olan ülkelerin temsiline bu ortamlarda ayrı bir özen ve ilgi gösterilmesi gerekmektedir. Rogerson (2000, s. 419), bir bilgi rejiminin var olmadığını ve hatta uluslararası iletişimde tek bir rejimin mümkün olamayacağını açıklarken, temelde uluslararası iletişimin liberalizmin kompleks bağımlıık kavramıyla açıklanabileceğini, homojen bir yapı sergilemediğini ve farklı kulvarlarında bu bağımlılık ilişkilerinin; bazen eleştirel yaklaşımların savunduğu gibi yapısal bir sömürü ilişkisi, bazen küreselleşme, bazen aktörlerin hedeflerine göre entegrasyon, bazen de ortak kararların alınabildiği rejimler referans alınarak analiz edilmesi gerektiğini vurgulamaktadır. 


\section{iLETișiM DÜZENINDE REFORM ARAYIŞLARI}

Liberal teorinin uluslararası işbirlikleri için temel platformlar olarak gördüğü uluslararası örgütler, uluslararası iletişimin küresel yönetişime evrilme eğiliminde olan rejimlerinde temel aktörlerdir. Bu örgütler arasında Birleşmiş Milletler'e (BM) bağlı olarak çalışan ITU; radyo frekansları, uydular, fiber optik ağlar, internet bant genişliği, kablosuz telefon gibi konularda düzenlemeleri yapan ve koordinasyon sağlayan bir örgüttür. Bu altyapı, yeni medyanın da temelini oluşturan telekomünikasyon sistemlerinin tamamıdır. Küresel telekomünikasyon sistemi küresel ekonominin adeta sinir sistemidir (McPhail, 2010). Gelişmekte olan ülkeler (bağımlılık teorilerine göre yarı çevre ve çevre konumundaki ülkeler) için sayısal eşitsizlik bu düzen ile ilişkilendirilen yapısal bir sorundur. 1970'li yıllardan itibaren özellikle BM'de UNESCO çatısı altında başlayan ve artan talepler, Yeni Küresel Bilgi ve Iletişim Düzeni'ne (New World Information and Communication Order-NWICO) yönelik ITU platformundaki tartışmalara da yansımıştır. Bu küresel konferanslara fonksiyonalist/işlevselci bir yaklaşımla teknik koordinasyon için teknokratların ve mühendislerin katılımının yeterli olmadığı, bunun yanında üye devletlerin sosyo-ekonomik ve kültürel durumlarının da değerlendirilmesi gerektiği görüşü güçlenmiştir (McPhail, 2010, s. 104). Bilgi toplumunda devletlerin telekomünikasyon ağına bağı olmadan gelişmeleri mümkün değildir, ancak bu ağda gelişmiş (merkez) ülkelerin en ileri iletişim teknolojilerine sahip olmaları, iletişim düzeninde daha belirleyici olmaları sayısal eşitsizliği körüklemektedir. 1970'li yılların ikinci yarısındaki NWICO talepleri, "dört D" adı verilen democratization (demokratikleşme), decolonization (sömürgecilikten kurtulma), demonopolization (tekellerden kurtulma) ve development (kalkınma)" kavramları etrafında şekillenmiştir (Carlsson, 2003, s. 40).

1980 UNESCO Genel Konferansında sunulan MacBride Raporu uluslararası iletişim alanında gelişmekte olan ülkelerin taleplerinin simgesi haline gelmiştir. Ancak 1980 'ler önceki on yılların iyimserliği ve reform havasını taşıyamamıştır. Bunun başlıca nedeni liberal ekonominin serbestlik, ticarileştirme, tüketim ve bireycilik kavramlarının ön plana çıkmasıdır. 1990'ı yıllarda bu eğilimlerin küreselleşme ve karşılıkı bağımlılık ekseninde giderek daha etkili olmaları, medyanın küreselleşmesini de zirveye taşımıştır. Özellikle iletişim uyduları, sayısallaşma ve internet, medya kuruluşlarının ürün ve hizmetlerine sınırsız bir pazar olanağı sağlamıştır. İletişim sektöründeki küresel aktörler, özellikle haber ajansları, 1990'ı yıllardan itibaren gelişmekte olan ülkelerin yeni kurulan ajansları ile işbirliğine başlamış 
ancak bu ortaklıkların yol haritaları devlet politikalarından çok, medya kuruluşlarının inisiyatifleriyle çizilmiştir (Carlsson, 2003, s. 54-57). Bu noktada, daha eşitlikçi ve adil bir bilgi akışına yönelik umutlar, artık ulusötesi bilgi topluluklarının etkilerinin artmasına yönelik beklentilerle beslenmektedir.

2000'li yıllarda ITU toplantıları çok hızlı gelişen iletişim sektöründeki binlerce kişiden oluşan delegasyonların katıldığı platformlara dönüşmüştür. ITU'da üye olarak 193 ülke, 900'ün üzerinde sektör temsilcisi şirket, akademik kurum, STK'lar, bölgesel örgütler yer almaktadır. Gelişmekte olan ülkeler, BM'nin UNESCO, ITU gibi platformlarında ulusal egemenliklerini koruma ve uluslararası siyasi ekonomide tam egemen devlet olma çabasındadırlar. Gelişmiş devletler ise bu mücadeleyi sözde destekleyerek, işlemlerin ticarileştirilmesini, rekabet artırıcı önlemleri benimseyen politikalara öncelik vermiştir. Gelişmekte olan ülkelerin gündeme taşıdığl; devlet sorumluluğu, enformasyon denetimi ve evrensel mesleki etik/ahlak kuralları gibi kavramların, iletişim özgürlüğü ve serbest bilgi akışıyla bağdaşmadığı öne sürülmüştür. Ancak gelişmiş ülkelerin bu uygulamaları neoliberal tezlerle çelişmektedir. Diğer taraftan neo-Marksist bağımlıık teorileri, gelişmiş ülkelerde de medyanın devlet denetiminden tümüyle bağımsız olmadığını ve ulusötesi sermayenin ulusal egemenliği kendi çıkarları önünde bir engel olarak gördüğünü tartışmaktadır (Akdemir, 2002, s. 250). Dolayısıyla bu eşitsiz durum aslında devletlerin ortak sorunudur ve rejimler yoluyla aktörlerin rol ve sorumlulukları, rekabet kuralları tekrar tanımlanabilir. Çok uluslu şirketler, aynı mesajlarını ve yayın içeriklerini; orijinal/aynı dilde küresel kanallarıyla, yerel dillerde ise bölgesel dağıtım kanallarıyla paylaşmakta ve bilgiye erişim için gereken teknik sistemleri de sağlamaktadır. Bu ticari ağlar, farklı medya sektörleri arasında yatay ve dikey büyümeyle (örneğin gazetecilikten televizyonculuğa ve müzik/kitap yayıncılığına geçen kuruluşlar yoluyla) yaygın etkisini daha da arttırmaktadır. Dolayısıyla UNESCO'nun, gelişmekte olan ülkelerin kendi ulusal/yerel ağlarıyla küresel ağa bağlanmaları gerektiği öngörüsü, asimetrik karşılıklı bağımlılı̆ı sonlandırmaktan henüz uzaktır. Bu arada dünya nüfusunun çoğu küresel ağa bağı değildir, gençler ve çocuklar gelişmiş ülkelerdeki akranları gibi çoklu medya jenerasyonu veya bu teknolojilere doğan dijital yerliler de değildir.

Yeni Illetişim Düzenine (NWICO) dair taleplerin bugüne kadar başarısız olmasının nedeni, güçlü devletlerin ve uluslararası iletişim hizmetlerini yoğun kullanan devlet dışı aktörlerin bu hizmetlerin liberalleşmesi konusunda aynı tarafta ve işbirliği halinde olmalarıdır. Singh'e göre (2010, s. 17) aslında telekomünikasyon rejiminde ilke ve normlar hiçbir zaman değişmemiştir. Sadece değişen teknoloji ve küresel rekabet, rejimin kurallarını ve karar alma prosedürlerini yeniden ve yeniden güçlü olanın lehine 
şekillendirmiştir. Uluslararası iletişimde mikro ve makro düzeylerde koordinasyon ve işbirliği için yapılan müzakereler ortak problemlerin çözümü için arayışları içermektedir. Bu müzakerelerde farklı koalisyonlar söz konusudur. Tüm paydaşlarca üzerinde anlaşılan ortak tercihin, daha eşitlikçi ve adil bir düzene geçiş olması ve iletişim etiğinin içtenlikle ve evrensel değerler bağlamında tartışılması için daha hümanist yaklaşımlar gerekmektedir. Liberalizmin, asimetrik olmasını doğal saydığı karşııılı bağımlılık yaklaşımı böyle bir ortamı sağlamaktan uzaktır. Karşııklı bağımlılığın da etik olarak tartışılması ve kültürlerarası boyutlarıyla ele alınması gerekmektedir. Çünkü yumuşak güce dayansa da farklı aktörlerin tercihlerini yansıtmayan ve diğer toplumların ihtiyaçlarını karşılamayan politikalar küresel yönetişimin bir parçası olamaz. Ulusötesi bilgi toplulukları ve küresel sivil toplumun yeni küresel ortak değerlerin oluşturulmasında sinerji yaratması ve küresel liberal düzene önce iletişim alanından başlayarak reformlar getirmesi küresel bir beklentidir. Hem realist hem liberal bakış açısıyla uluslararası iletişimde; sivilleşme, çoğulculuk ve demokratikleşme yanında özellikle barış, özgürlük, denetim ilkesi (bütünlük) ve egemenlik dikkate alınması gereken ilkelerdir (Akdemir, 2002, s. 253-254). Enformasyon kaynaklarının ve akışın dağııımındaki dengesizlikler, gelişmekte olan ülkeler kadar gelişmiş ülkelerin de sorunu olarak görüldüğünde, uluslararası iletişimde demokratikleşme mümkün olabilecektir (Akdemir, 2008, s. 113). Yeni uluslararası bilgi düzeni tartışmalarını gelişmekte olan ülkelerin kalkınma sorunlarından bağımsız düşünmek tabi mümkün değildir. Kültürel kimlik, kendi kendine yeterlilik, erişim ve katııım kavramları; artık modernleşme ve bağımlılık kavramlarına tercih edilerek evrensel modeller yerine her ülkenin/ulusun kendi çözümlerini bulması gerektiğine vurgu yapılmaktadır. Demokratik süreçlerin, insan haklarının korunması ve topluma yerleşmesi süreçleri için yine toplumların kendi geleneksel değerleri ve sosyalleşme süreçlerine göre stratejilerin belirlenmesi önemlidir (Carlsson, 2003, s. 60).

Yeni medyanın altyapısını kurduğu ağ toplumu; kültürlerin melezleşmesine sağladığı ortamla, ulusal çıkar ve politikaların birbirini karşılıkı yapılandırdığı, küresel medya düzeninin daha kompleks ve çokuluslu hale geldiği bir dönüşümü de tetiklemiştir. Enformasyonun dengeli ve daha adil akışına yönelik çözüm önerilerine küresel piyasa ekonomisinin rekabetçi şartları ve serbest bilgi akışının yumuşak güç adı altında meşrulaşması şans tanımamıştır. Demokratik rejimlerin güçlenebilmesi için medyanın toplumsal ve küresel sorumluluk bilinciyle çalışması ve bilgiye erişimde engellerin kaldırılması gerekir (Uzun, 2016, s. 327). ITU ve UNESCO'nun daha kapsayııı ve katılımcı bir Bilgi Toplumu oluşturulması ve sayısal bölünmenin giderilmesine ilişkin çağrılarında liberal ilkeler, fırsat eşitliği iletişim hakkı daha çok 
vurgulanmalıdır. Liberal argümanlar, devlet dışı aktörlerin, kamuoyunun hümanist ortak değerlerin oluşumuna ve demokratik siyasal değerlerin yayılmasına etkilerinden bahsederken aynı zamanda karşııklı ekonomik bağımlılığın ve özellikle dış ticaretin devletler arasındaki çatışma ve sorunları azaltan doğasına dikkat çekmektedir. Bu ise kompleks bağımlılı̆ın daha adil bir düzen için kullanılması ve ilkelerin toplumların siyasi, ekonomik ve kültürel şartlarına uygun olarak değerlendirilmesini ve tekrar belirlenmesini gerektirmektedir. Kurulan ekonomik ilişkilerin ve yaratılan karşııkı bağımlılıkların liberal öngörüyle toplumlar arasında barışı tesisi için bunun tek taraflı sömürü ilişsisine dönüşmemesi, ortak politika oluşturma süreçlerinde karşılıklı saygı, anlayış ve uzlaşının sağlanması ve kamuoyları nezdinde de diplomasi yoluyla kararların desteklenmesi önemlidir. Yeni medya ile desteklenen katılımcı demokrasinin ve kamu diplomasisinin de gereği budur.

\section{SONUÇ}

Uluslararası iletişim düzeninde, daha eşitlikçi ve adil bir bilgi akışı, gerçek anlamda küresel bir enformasyon toplumu ve bu ortak ilkeleri destekleyen kamu diplomasisi stratejileri ve bunlara göre işleyen küresel yönetişim mekanizmaları için kat edilmesi gereken yol fazladır. Ancak uluslararası iletişimde yapılacak her reform hareketi uluslararası siyasete de doğrudan etki edeceği için öncelikli alan olarak görülmelidir. Realist yaklaşımlar çözüm üretmek yerine var olan sistemin özelliklerine gerekçeler sunuyor görünmekle birlikte, karşılıklı bağımlıı̆ı̆ın etkisiyle devlet dışı aktörlerin etkileri ve uluslararası sistemi sosyal bir yapı olarak da görme eğilimindedir. Liberalizmin normatif ve özgürleştirici özünün (bireyin özgürlüğü ve gelişimine odaklanan temel varsayımlarının) uygulamadaki zayıflı̆̆ı ise uluslararası ilişkilere tam olarak yansıtılamamasından kaynaklanmaktadır. Sosyal ve kültürel unsurların ortak çıkar tanımlama süreçlerine katılması, liberal kurumsallaşmanın uluslararası boyutta daha fazla desteklenmesi gerekmektedir. Ancak bunlar yumuşak güç ve daha fazla kültürlerarası iletişimle sağlanabilecek iyileştirmelerdir. Bağımlıık teorileri var olan eşitsiz durumun bir tespitini yaparak düzendeki yapısal sorunları ve liberal ekonominin sebep olduğu sömürüyü eleştirmektedir. Ekonomik düzendeki yapısal sorunların çözümü ve daha sosyal politikalar için de öncelikli konu var olan platformlarda daha fazla temsil ve ortak çıkarların tanımlanmasına imkan sağlayan iletişim ortam ve politikalarının oluşturulması olacaktır. 
Uluslararası sistemde baskın realist ve liberal paradigmaların son on yıllarda varsayımları birbirine çok yakınlaşmış olup, yorumsamacı yaklaşımların eleştirilerinden de etkilenmişlerdir. Uluslararası iletişim bağlamında özellikle reform açısından bakıldığında liberal kuramın özü nedeniyle etik değerleri ve dönüşümü tartışmaya daha açık olduğu görülmektedir. Neoliberalizmde sosyolojik analizlerin sosyoekonomik ve kültürel farklııkları dikkate alabileceği ancak liberal siyasette iç ve dış politikanın kuramın söylemlerindeki kadar iç içe olmadığı dikkat çekmektedir. Liberal ideallerin ne derece izleneceğine devletlerin kendi iç siyasi gelişmeleri ve sosyal hareketliliği yön vermektedir. Ağ toplumu yapısı ve yeni medyanın sunduğu olanaklara rağmen bireyler, gruplar dış politikayı yönlendirmede lokomotif etkiye sahip değildir. Liberalizmin küresel yönetişim anlayışı bireylerin eşitliği ve özgürlüğü temeline dayanır ancak daha adil bir düzenin anahtarı olarak görülebilmesi, çok kültürlü bir kalkınma ve gelişme anlayışına sahip olmayı gerektirmektedir. Tıpkı küreselleşmenin her toplum için aynı anlamı taşımadığı ve aynı etkileri doğurmadığı gibi liberal değerler de evrensel değildir. Batı değerlerine dayalı geleneksel liberalizm teoride güçlüdür ancak uygulamada kronikleşen sorunları çözmekten ve yaygın etkiye sahip olmaktan uzaktır. Liberal anlayışta iç siyasette birey için iyi olan topluma da fayda sağlar ancak çıkarların uyumu ilkesi uluslararası düzeye taşındığında farklılaşan ulusal çıkarlar nedeniyle başarısız olmaktadır. Siyasi ve ekonomik farklılıklar yanı sıra kültürel farklııklar da homojen olmayan uluslararası toplumun iletişim intiyaçlarının aynı mekanizmalarla karşılanamaması sonucunu doğurmaktadır. Kültürel farklııkların dikkate alındığı, çok disiplinli yaklaşımlarla iletişim düzenin sorgulandığı araştırma ve projelere ihtiyaç duyulmaktadır.

Uluslararası ilişkilerin düzen-adalet ikileminde düzen tercih edildikçe, insancıl ve etik çözümlerin üretilmesi zordur. Uluslararası iletişimde tercihlerin dezavantajlı toplumlar düşünülerek ve enformasyon etiği gözetilerek yapılması, küresel sorunlara ortak çözümler getirebilmek için gerekli bir şarttır. Varolan düzende liberal bir reform yapılamamasının temel nedeni uluslararası toplumun birey düzeyinde değil devletler düzeyinde analiz edilmesi ve Batı değerlerine göre kurgulanmış olmasıdır. Rekabetçi siyasi ortamda uluslararası hukuk, uluslararası örgütler ve kurumlar adil bir düzen için yetersiz kalmakta ve hatta devletlerin, şirketlerin kendi çıkarları için kullandıkları platformlara dönüştürülmektedir. Bilgi toplulukları, STK'lar gibi ulusötesi aktörlerin bu platformlara artan katılımları umut uyandırsa da devletlerin tekelleri ve hegemonyasından çıkarılmaya çalışılan iletişim rejimleri bu sefer de hızlı özelleşme ve ticarileşmeyle küresel şirketlerin kontrolüne girmiştir. Ancak bu devletler için ortak bir 
sorundur. Günümüzde neoliberalizm normatif tartışmalar yerine uluslararası ilişkilerde sosyolojik analizlere girişmiştir ve her şeyi toplumların sosyokültürel özelliklerine ve iç siyasetlerine göre açıklama eğilimindedir. Oysa evrensel değerlere ulaşılabilmesi için daha kapsayıcı değerler ortak inşa edilmeli, ülkeler ve toplumlar kategorize edilmemelidir. Aslında iletişim düzenine daha eşitlikçi bir yapı getirmek gibi görünen bu yeni düzen arayışı, küresel sorunların çözümü için temel bir anahtardır. Devletlerin ve diğer devlet dışı uluslararası aktörlerin, küresel çıkarları tanımlamaları, kamu diplomasisi ve kültürlerarası iletişimle toplumların öznel durum ve ihtiyaçlarını ele alan ve enformasyon etiğini gözeten çokkültürlü iletişim anlayışıyla geliştirilebilir. Karşılıkı bağımlııktan bu reform ortamını oluşturması için de istifade etmek elzemdir.

\section{EXTENDED ABSTRACT}

The reason for intensification of debates about reform in international communication order, emanates from the asymmetry in mutual interdependence in international relations. The new global order is far away from the universalization of values. The root cause is the multiplication of inequalities among nations. Globalization isnot democratic and equal in terms of technological and financial infrastructure and access to information. The ease of access through the use of new communication technologies works for those, that have the skills and abilities for internationalization and mobility. The disadvantaged status of the developing nations leads them to demand reform and cause instability in relations, the global turn of which is more protectionist policies by developed countries.

In the literature, this dilemma is mostly studied through political economic lenses of the critical theory. The major paradigms, realism and liberalism in International Relations have shaped the structure of this order based on power relations and the efforts for a reform have been far away from meeting the expectations. The purpose of this paper is to approach the problem differently and investigate the potential of these theories for a reform. In the neorealist and neoliberal analyses, the sociological and normative concerns are increasingly taken into consideration also owing to increasing mutual interdependence with globalization. Therefore, in this theoretical paper, a descriptive and comparative analysis of the concepts mutual interdependence and reform is made according to (1) information society, (2) intercultural communication and public diplomacy and (3) global governance that involve different levels of analysis in international communication. The theoretical framework is constructed on 
realism and liberalism because of the thesis that a discussion on reform according to their perspective may prove more fruitful since the communication order is already based on realist and liberal concepts and arguments. In the quest for reform, the issue areas that require policies and action are a global information society, public diplomacy for an international public opinion and an effective and just global governance through initiatives of the international organizations.

International communication order, far from emancipatory promises of liberal values, has evolved into a network of hegemonies. As the global corporations aim to become monopolies in the production, distribution and transmittance; convergence in telecommunication technologies for information and entertainment services has helped the process to their advantage. Realist and liberal paradigms see this uneven competition as part of their rationality assumption in the quest for power. However according to sociologist Castells, information society is the phase of capitalism where information determines the social relations as the basic resource for production and basic commodity to be consumed. In such social structure, new media is the environment for information to be shared, together with other mass communication media where power relations are both shaped and confirmed (2007). The result is the network society where the economic production and relations are based on the access to information resources. This is why information is argued to be the basis of capitalist production. This critical approach to capitalism and other similar structural analyses based on political economy discuss for a structural reform. Is it possible to open doors for reform according to realist and liberal rules of the game? Though the liberal paradigm underlines the emancipatory effects of the liberal network society on the individual, the digital divide reminds that the expectation is naive. Which other options remain then?

This asymmetry of power in the information society is especially felt by the developing nations, through the public diplomacy channels. The increasing awareness about the effects of intercultural/transnational communication has also triggered the will of governments to increase their soft power on the international public opinion. The increasing number of actors in international relations has resulted in the willingness of international organizations, media corporations, non-governmental organizations, interest groups and individuals to be part of global public diplomacy. The liberal theory explains this with the increasing role of the public opinion in foreign policy and according to some liberals, the evolution of the international society towards a cosmopolitan one. The realist and more classical 
understanding of diplomacy as the communication between governments through formal representatives has been criticized for neglecting the transnational communication networks. The liberal foreign policy analyses have emphasized the roles of socioeconomic elite, political elite, media, opinion leaders in shaping foreign policy in democracies. Public diplomacy may provide platforms for the disadvantaged societies to declare their demands for reform besides providing the advantaged societies new opportunities due to their soft power. Since the calls of developed countries for democratization of all societies are motto of their liberal policies, these governmental and non-governmental channels must be used efficiently by all parties.

In the global governance of communication; the international regimes established can be seen as new forms of socialization that increase leverage of free trade in communication services (Singh, 2010). Different classifications are made in the literature for these regimes, generally speaking, telecommunications regime is separated from the governance of the internet and electronic trade due to the different nature of actors involved. The regimes provide common norms, rules accepted and monitored through international agreements. The regimes in different issue-areas may necessitate realist, liberal or constructivist (cognitive) analyses in explaining the behaviors of the actors and the potentials of conflict and/or cooperation. The realist explanations concentrate on the state power, the liberal view bases its rationale on the mutual interdependence and global economy, and the cognitive approach brings forth the epistemic communities such as the engineers, technicians, economists, scientists, field experts in global governance of communication issues. This transnational network provides new areas for empowering the developing countries and creating opportunities for the involvement of their needs and values, in shaping global strategies and policies. The national interests of states shaped through realist and liberal mentality sometimes cast shade on these expectations. Still non-governmental organizations, associations for civic engagement and individuals attempt to include more voice from developing countries to prevent the failure of the calls for a truly global information society.

International organizations, governmental and non-governmental are also major actors in the communication regimes that are expected to contribute to global governance. Among them, International Telecommunication Union (ITU) is a specialized United Nations (UN) agency devoted to coordination and regulation of radio-frequency spectrum allocation, satellite orbits, fiber optic networks, 
internet bandwith, wireless communication and broadband services. This is the infrastructure that provides whole telecommunication systems including the new media. Global telecommunication system is the nervous system of the global economy (McPhail, 2010). The digital divide, a major issue on the agenda of organizations like ITU, is a structural problem related with the infrastructural gap due to which, some countries are underserved. The inefficiency of the calls and demands for New World Information and Communication Order (NWICO) stems from the unwillingness of the developed countries and nongovernmental actors that benefit more from international communication services. The asymmetrical mutual interdependence of liberal economy, doesnot easily provide the means to initiate cooperation with them for the norms of the new order. However, communication needs to be the priority in negotiations for trade preferences and related agreements.

The priority of order, in the debate "order versus justice" in international politics, prevents societies from producing creative and humanistic solutions. The digital divide and related regulatory problems in international communication order are in fact key to solution of other global issues as well. The difficulty of a liberal reform is because analyses are based on states or an international society constructed on Western values. The increasing number of non-state actors hasnot been promising since this has opened the doors for the hegemony of media corporations and their rivalry for monopoly. The sociological discussions in neoliberalism need to be enriched by normative discussions about more inclusive, multicultural values around which global norms can be built. Intercultural communication and public diplomacy can be the means for building a global information society and an ethical and multicultural communication order that can better serve the needs of all peoples.

\section{KAYNAKÇA}

Akdemir, S. (2002). Enformasyon egemenliği. Kurgu Dergisi, 239-255.

Akdemir, S. (2008). Uluslararası enformasyon akışı: kavramsal bir çözümleme. Galatasaray Üniversitesi iletişim Dergisi, 9, 101-122.

Arı, T. (2013). Uluslararası ilişkiler teorileri. Bursa: MKM.

Atabek, Ü. (2013). Yeni medya ve yeni iletişim düzeni. Mülkiye Dergisi, 37(3), 175-181.

Binark, M., \& Bayraktutan, G. (2013). Ayın karanlık yüzü: yeni medya ve etik. İstanbul: Kalkedon.

Carlsson, U. (2003). The rise and fall of NWICO: from a vision of international regulation to a reality of multilevel governance. Nordicom Review, 24(2), 31-67. 
Castells, M. (2007). Communication, power and counter-power in the network society. International Journal of Communication, 1, 238-266.

Demir, V. (2012). Değişen uluslararası ilişkiler çerçevesinde kamu diplomasisi ve halkla ilişkilerin müşterek kavramları. M. Bostancı içinde, Uluslararası iletişim ekonomi politiği (s. 243-279). İstanbul: Chiviyazıları.

Hallin, D. C., \& Mancini, P. (2004). Comparing media systems: three models of media and politics. UK: Cambridge University Press.

Hofstede, G. (2015). National differences in communication styles. D. Brzozowska, \& W. Chlopicki içinde, Culture's software: communication styles (s. 1-14). UK: Cambridge Scholars.

Humphreys, P. (2012). A political scientist's contribution to the comparative study of media systems in Europe: a response to Hallin and Mancini. M. Puppis, \& N. Just içinde, Trends in Communication Policy Research: New Theories, Methods and Subjects (s. 157-177). UK: Intellect.

Kartarı, A. (2014). Kültür, farkılık ve iletişim: kültürlerarası iletişimin kavramsal dayanakları. İstanbul: Illetişim.

Keohane, R., \& Nye, J. (1998). Power and interdependence in the information age. Foreign Affairs, 77(5), 81-94.

Krasner, S. D. (1982). Structural causes and regime consequences: regimes as intervening variables. International Organization, 36(2), 185-205.

Krasner, S. D. (1991). Global communications and national power: life on the pareto frontier. World Politics, 336-366.

McPhail, T. L. (2010). Global communication: theories, stakeholders and trends. UK: Wiley-Blackwell.

McQuail, D., \& Windahl, S. (2010). Iletişim modelleri. (K. Yumlu, Çev.) İmge.

Meyer, E. T. (2005). Communication regimes: a conceptual framework for examining IT and social change in organizations. ASIST (American Society for Information Science and Technology).

Moravcsik, A. (2010). "Wahn, wahn, überall wahn": a reply to Jahn's critique of liberal internationalism. International Theory, 2(1), 113-139.

Moravcsik, A. (2013). The new liberalism. R. E. Goodin içinde, The Oxford Handbook of Political Science.

Morley, D., \& Robins, K. (2011). Kimlik mekanları. (E. Zeybekoğlu, Çev.) İstanbul: Ayrıntı.

Mowlana, H. (1985). International flow of information: a global report and analysis. UNESCO Digital Library. https://unesdoc.unesco.org/ark:/48223/pf0000065258 adresinden alındı

Nye, J. (1988). Neorealism and neoliberalism. World Politics, 4O(2), 235-251.

Nye, J. S. (2004). Soft power: the means to success in world politics. New York: Public Affairs.

Nye, J., \& Welch, D. (2009). Küresel Çatışmayı ve Iş̧birliğini Anlamak. (R. Akman, Çev.) İstanbul: Iş̧ Bankası Kültür Yayınları.

Özen, Ç. (2019). Uluslararası örgütler teorisi. Ç. Özen, \& Ö. Tonus içinde, Uluslararası örgütler (s. 2-31). Eskişehir: Anadolu Üniversitesi Yayınları. 
Prensky, M. (2001). Digital natives, digital immigrants. On the Horizon, 9(6).

Rogerson, K. (2000). Information interdependence: Keohane and Nye's complex interdependence in the information age. Information, Community \& Society, 3(3), 415-436.

Ruggie, J. G. (1975). International responses to technology: concepts and trends. International Organization, 29(3), 557-583.

Siebert, F. S., Peterson, T., \& Schramm, W. (1956). Four theories of the press. USA: University of Illinois Press.

Singh, J. P. (2010). International coommunication regimes. Oxford Research Encyclopedia, International Studies. içinde International Studies Association and Oxford University Press.

Timisi, N. (2003). Yeni iletişim teknolojileri ve demokrasi. Ankara: Dost Kitabevi.

Uzun, R. (2016). Illetişim etiği: sorunlar ve sorum/uluklar. Ankara: Dipnot.

Viotti, P. R., \& Kauppi, M. V. (2012). International relations theory. USA: Pearson.

Wendt, A. (1992). Anarchy is what states make of it: the social construction of power politics. International Organization, 46(2), 391-425. 